\title{
Analysis of Supplier Selection by Using the AHP and PROMETHEE Methods in Regional Public Hospital Padang (RSUD Padang)
}

\author{
Syarah Raudhatul Rahmi ${ }^{1}$, Firman Firman ${ }^{2 *}$ \\ ${ }^{1}$ Padang State University, Padang and Indonesia, $\square$ firmanfeunp@gmail.com \\ ${ }^{2}$ Padang State University, Padang and Indonesia, $\square$ syarah93gmail.com \\ *Corresponding Author
}

\begin{abstract}
This study aims to prioritize the main criteria in the selection of suppliers at RSUD Padang and to find out which supplier is the best in RSUD Padang.This study analyzes the selection of suppliers at RSUD Padang. The data used are primary data obtained through the distribution of questionnaires and secondary data obtained from company documents. The method used is the Analytical Hierarchy Process (AHP) and the Preference Ranking of the Organization Method for Enrichment Evaluation (PROMETHEE). The results of this study indicate the priority of the main criteria that can be used by the hospital is the quality criteria that have a weight value of 0.36 . Then the next result is the best supplier at RSUD Padang, namely supplier B, which has the highest net flow value with a net flow value of 0.15 . While suppliers that have the lowest net flow value are supplier $C$ with a net flow value of -0.36

Keywords: supplier selection, analytical hierarchy process, preference ranking of the organization method for enrichment evaluation
\end{abstract}

\section{Introduction}

In the era of industry that is getting tighter nowadays, all business people need to pay attention to all aspects of managing a business. One of the activities of managing a business in a company is managing the supply chain.Supply Chain Management (Supply Chain Management) is a process of planning, implementing and controlling operations of the supply chain that aims to meet customer needs as efficiently as possible.According to Heizer \& Render (2005) Supply chain management is an activity of managing activities in order to obtain raw materials, change the raw material into goods in the process and also finished goods. According to Stevenson \&Chuong (2010) the supply chain is a series of activities that exist in a company that includes the production and delivery of goods or services. In the supply chain or supply chain management there are several activities related to the continuity of the supply chain, one of which is supplier selection. The selection of the right supplier not only provides benefits, According to Nair \& Das (2015) the selection of the right supplier makes the purchasing performance better than the cost of quality, delivery, flexibility and innovation. Selection of suppliers is an activity related to the purchase of raw materials or needs that must be considered by the purchasing management in the company. If the process is done correctly, higher quality, longer lasting relationships can be achieved (Özkan, Başlıgil, \&Şahin, 2011).

In supplier selection there are several strategies that can be used by companies in choosing their suppliers, but which are often used by companies there are two strategies namely many suppliers and few suppliers (Heizer \& Render, 2005). In evaluating and selecting suppliers effectively and efficiently, the company will involve many things and decisions to be taken including, according to Monczka\&Handifield (2005) first identify the need for supplier selection after identifying the required resources, then determine the source strategy power, identification of potential supply sources, limiting suppliers within the scope of selection, then determining supplier evaluation and selection methods and the last supplier selection and achieving agreement.

In selecting suppliers there are also criteria that must be taken into consideration by companies in choosing their suppliers. Some of the criteria that many consider the company in selecting suppliers such as quality, price, material, shipping, etc. Lin, Chen, \& Ting (2011) developed several criteria that can be used, namely price, quality, service, delivery accuracy and trust.In 1966, Dickson stated that 
there were 23 criteria that could be used in supplier selection. In this study a survey was conducted on the expert to determine the weight of interest in each criterion. Then the results show that there are 4 levels of importance, extreme importance, considerable importance, average importance and slightly important. While the supplier selection criteria according to Nydick\& Hill (1992) criteria are quality (price), price (price), service (service) and delivery (delivery).

Hospital is a facility that must exist in an area. One of the hospitals in the city of Padang is the RSUD Padang. At RSUD Padangmanaging the supply chain is a very important activity. One of the activities in managing the supply chain at RSUD Padangis to select suppliers. Selection of suppliers in hospitals is one of which occurs in pharmaceutical drugs. In addition to pharmaceutical drugs, there are several fields that also use supplier assistance such as BHP (consumables), patient food, and medical devices. Suppliers used in pharmacy as well as several other fields, as follows:

Table 1 Suppliers at RSUD Padang

\begin{tabular}{ll}
\hline Field & \multicolumn{1}{c}{ Supplier } \\
\hline Pharmaceutical drug & Actavis, Astrazenica (APL), Bernofarm, Beta Pharmacon, \\
& Biofarma, Beohringer, Darya Varia, Dexa Medica, \\
& Etercon, Ethica (APL), Frasenius, Galenium, Glaxo \\
& wellcome, Holi, Ikapharmindo, Indofarma, Kalbe Farma, \\
& Kimia Farma, Lucas Djaya, Marin,Meprofarm, Merck, \\
& Mersifarma, Molex Ayus, Nova pharin, Novell, Otsuka \\
& Indonesia, Otto, Phapros, Pharmalaboratoris, \\
& Phytokemo, Pratapa Nirmala, Promed Rahardjo, Rama \\
& Emerald, Soho, Tanabe Indonesia, Tempo Scan Pasific, \\
& Widatra, Yarindo \\
\hline BHP & PT. Global Dispo Medika, PT. Roche Indonesia, PT. Bio \\
& Axion, PT. Terumo, PT. B.Braun Medical Indonesia. PT. \\
& Covidien Indonesia, PT. BSN Medical Indonesia, PT. \\
& Unolab Mitra Persada, PT. Jayamas Medika, PT. Enseval \\
& Medika Prima, PT. Sentral Asia Gemilang, PT. Anugrah \\
& Argon Medica, PT. Medibest Indonesia. \\
\hline PT. Bagindo \\
\hline
\end{tabular}

Source : RSUD Padang

In fulfilling the supply chain, most hospitals use many suppliers to meet their needs. Based on the results of supplier selection observations at RSUD Padang, there was no system in selecting suppliers because the supplier selection was carried out by the government. In this case the Hospital does not have criteria to evaluate their suppliers and is not very aware of the advantages of their respective suppliers. For this reason, it is necessary to evaluate suppliers from several suppliers that are used so that the Hospital knows their suppliers. To conduct supplier selection or supplier evaluation at RSUD Padang, several criteria can be used which are considered relevant to the needs of drug suppliers. Criteria that can be used are quality, price, payment flexibility, order fulfillment and time.

In previous studies in supplier selection there were several methods that have been used including the Goal Programming conducted by Kull and Talluri (2008) and Rajesh Sing, SK Sharma and Peeyush Pandey (2012), (Data Envelopment Analysis) DEA carried out by Wu and Blackhurst (2009) and Wan Lung Ng (2008), Non-Linear Programming was carried out by Hsu, et al (2010) and Nilesh R. Ware, .P. Singh, D.K. Banwet (2013), Techniques for Order Performance by Similiraty to Ideal Solution (TOPSIS) was conducted by Sevkli (2010) and KambizShahroudi and S. Maryam ShafaeiTonekaboni (2012), AHP and ANP conducted by Lin, et al (2010) and M. NavidKasirian, RosnahMohd. Yusuff and Ismail. YY (2010), Linear Programming was carried out by Lin, et al. (2011) and SH Ghodyspour, C. O'Brien (1998), Multi-Objective Programming conducted by Yu, et al. (2012) and Charles A. Weber and John R. Current (1993) and the AHP and PROMETHEE methods conducted by Bhavesh Kumar Shakey (2013), Emir Huseyinozder (2017) and Fugui Dong (2015). 
To deal with problems involving several criteria the hospital can use the AHP (Analytical Hierarchy Process) method. AHP method is one model of decision making that produces decisions through the weighting of criteria from each criterion (Nugroho B. Y., 2010). According Saaty (1993), hierarchy can be interpreted as a representation of a complex problem in a multi-level structure where the first level is the goal then followed by the factor level, criteria, sub criteria, and so on down to the last level of the alternative. In addition to using AHP as a decision-making method, the other method used in this study is the PROMETHEE method. Preference Ranking Organization Method The method for Enrichement Evaluation (PROMETHEE) is one of the priority or sequence determination methods in MCDM (Multi Criterion Decision Making) that uses an outrageous methodology to find alternative rankings (Yu et al., 2013).PROMETHEE Method (Preference Ranking Organization Method for Enrichment Evaluation) is a method of determining sequence or priority in several alternative choices evaluated with several different criteria (Macharis, Springael, De Brucker, \& Verbeke, 2004). The method is almost the same as the Mutiple Criteria Decision Aiding (MCDA) method (Corrente, Figueira, \& Greco, 2014). The PROMETHEE method is often used in choosing an alternative because this method is considered easier to implement than other methods (Murat, Kazan, \& Coskun, 2015). By using AHP, we will get the results of the weights of each criterion and using PROMETHEE will get the best supplier alternative rating used by the hospital. From the results of this alternative ranking, the hospitals will find out who their suppliers are the best in meeting their needs.

The conceptual framework in this study can be described as follows:

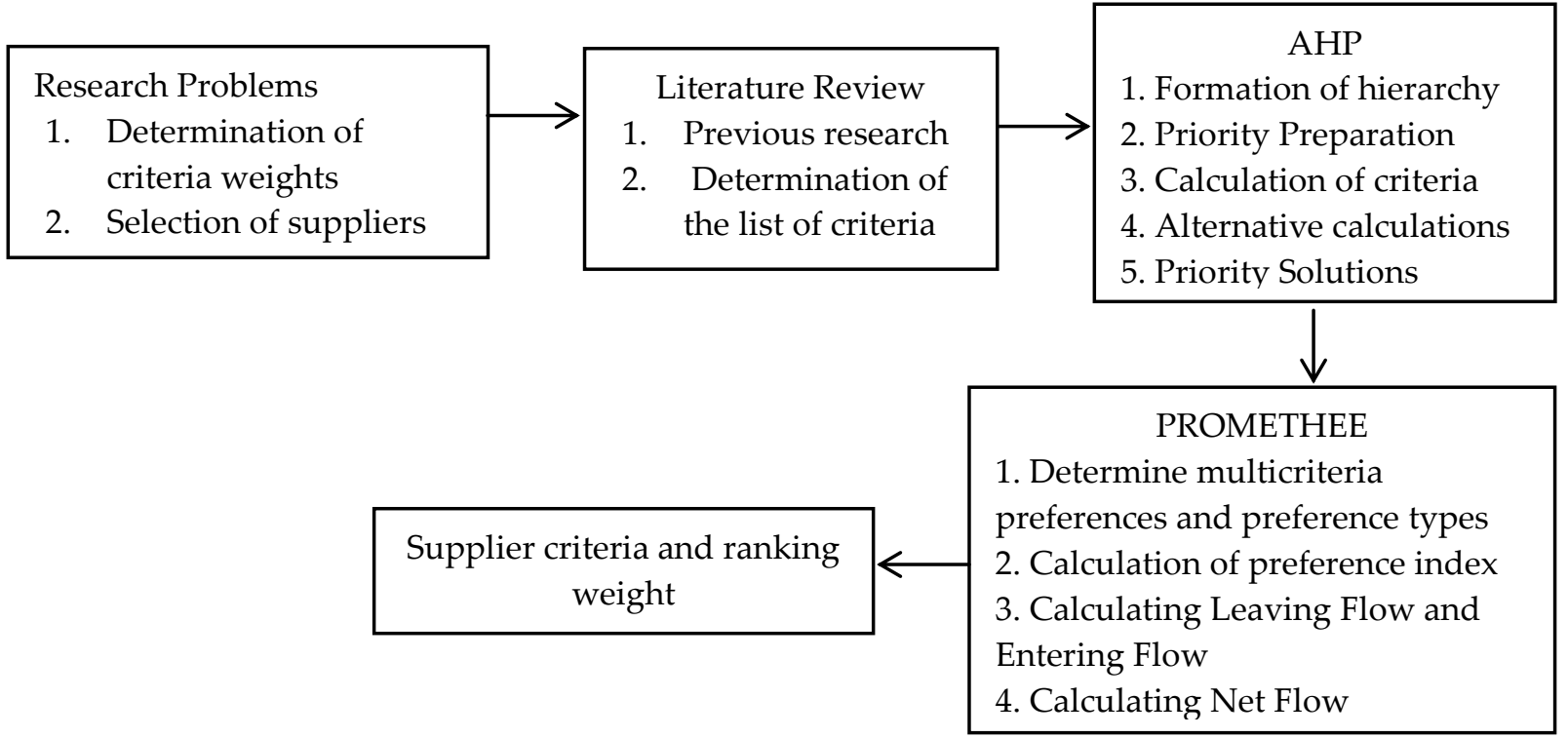

Figure 1 conceptual framework

\section{Methods}

This type of research is descriptive research. This study uses primary data obtained from the results of interviews and filling out questionnaires by the respondents concerned with the problem and this study also uses secondary data in the form of company documents related to drug suppliers. The operational definition used in this study is an operational definition of each criterion used in this study, the criteria used refer to previous research conducted by Anis, Listiyono, \&Khristianto (2015) following the operational definitions of several criteria used in this research :

1. Quality, which is the suitability of the quality of goods sent with specifications agreed upon by buyers and sellers. The quality of the drug can be seen from the form of the drug that is still intact and the function of the drug.

2. Prices, namely the price of goods offered by suppliers to those who want to buy. 
3. Payment flexibility, namely the ability of suppliers to respond to changes in demand, can meet changes in demand is an important factor in the selection of suppliers. In this case the buyer or consumer is given time in payment.

4. Order fulfillment, which is how much the supplier's ability to fulfill orders from consumers.

5. Time, namely the time in ordering products, where consumers want a short time in ordering products.

Furthermore, the data processing stage consists of processing using the analytical hierarchy process (AHP) method and the PROMETHEE method. AHP method is used to determine weighting, where the steps in the AHP method begin with the compilation of hierarchies, this hierarchy is structured to explain the problem in a structured and easily understood manner. Furthermore, doing priority calculations, the first thing to do in determining the priority criteria is to compile pairwise comparisons, by comparing in the form of pairs of all criteria, the comparison is then transformed into a pairwise comparison matrix. Then do the priority synthesis calculation, while the calculation in priority synthesis is by summing the values of each column in the matrix then dividing each value from the column with the corresponding column to obtain the normalized results of the matrix and finally summing the values of each matrix then dividing by number of elements to get an average value. The next step in the AHP method is consistency testing and formulas to measure consistency as follows:

Description: CI: Consistency index

$$
\mathrm{CI}=(\lambda \text { maks }-\mathrm{n}) /(\mathrm{n}-1)
$$

$\lambda$ : Eigenvalue

$\lambda$ maks: Eigenvalue maximum

$\mathrm{n}$ : Order matrix

Next measure the consistency ratio with the following formula:

$$
\mathrm{CR}=\mathrm{CI} / \mathrm{RI}
$$

Description: CR: Consistency ratio

CI: consistency index

RI: Random index

The permitted $\mathrm{CR}$ is $\mathrm{CR}<0.1$

If the value obtained is more than 0.1 or $10 \%$ then the assessment cannot be accepted, but if the assessment is less than 0.1 or $10 \%$ then the assessment results can be accepted.

Furthermore, in the PROMETHEE method this method is used to rank alternative suppliers, while the steps in processing data using PROMETHEE begins with the calculation of preference values, calculating the preference value which is the transformation of the difference between the criteria alternatives $(\mathrm{H}(\mathrm{d}))$ into the preference function. The value of $\mathrm{H}(\mathrm{d})$ is done by evaluating the value of the parameter ( $q, p$ or $s$ ) and the type of criteria that is appropriate for each criterion based on the maximization / minimization function. The type of preference criteria in this study is using linear preference types where by using the formula

$$
\begin{gathered}
\mathrm{H}(\mathrm{d})=\frac{d}{p} 0 \text { jika } d \leq 0 \\
\mathrm{H}(\mathrm{d})=\frac{d}{p} \text { jika } 0 \leq d \leq p \\
\mathrm{H}(\mathrm{d})=\frac{\mathrm{d}}{\mathrm{p}} 1 \text { jika } \mathrm{d}>q
\end{gathered}
$$

The next step in the PROMETHEE method is to find a preference index, the calculation of preference induction can be done with the following equation:

$$
\pi(a, b)=\frac{1}{k} \sum_{h=1}^{k} p_{h}(a, b)
$$

Then the next step of calculation in PROMETHEE is to avoid leaving flow, entering flow and the last net flow resulting from net flow will later result in ranking or alternative ranking. The following is a calculation of leaving flow, entering flow and net flow: 


$$
\begin{array}{r}
\text { Leaving Flow : } \emptyset^{+}(a)=\frac{1}{n-1} \sum_{x \in A} \rho(a, x) \\
\text { Entering Flow : } \emptyset^{-}(a)=\frac{1}{n-1} \sum_{x \in A} \rho(x, a) \\
\text { Net Flow : } \emptyset(a)=\emptyset^{+}(a)-\emptyset^{-}(a)
\end{array}
$$

\section{Results and Discussion}

\section{Determination of Respondents}

The respondent is someone who represents information about the supplier selection process, the respondent is someone who has experience in the process of selecting a drug supplier, and the respondent is the person who represents the authority in drug selection. Head of Medical and Medical Support Services, Head of Pharmacy Installation is the person authorized to make decisions in selecting drug suppliers

\section{Weighting with AHP Method}

With the existence of several criteria, a hierarchy of problems or decision structures needs to be made by making elaboration of criteria arranged in several levels. The following is a derivation of the hierarchy in the AHP method used:

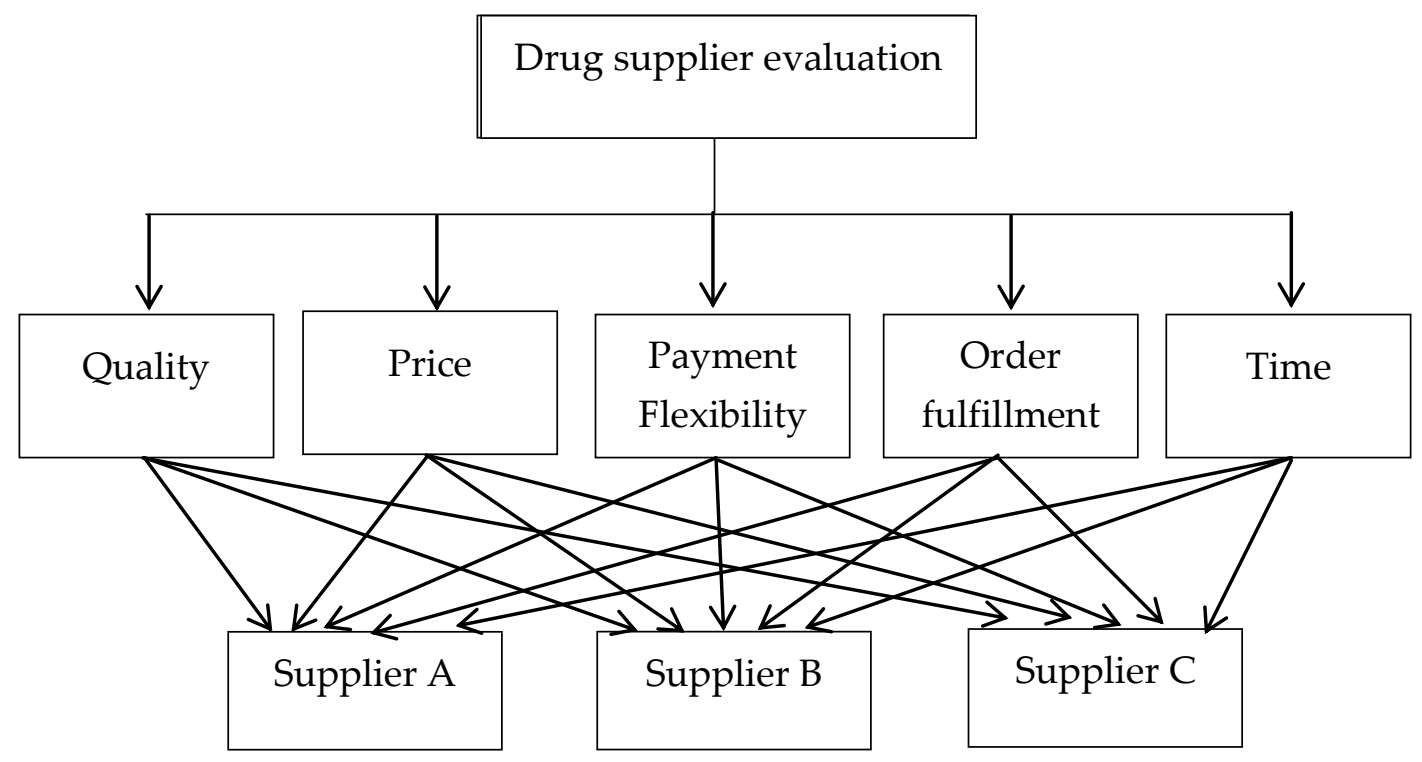

Figure 2 AHP Hierarchy of Research

Data obtained through distributing questionnaires to purchasing decision makers in RSUD Padang as seen in table 2 are processed using pairwise comparison matrices then weighted and consistency tests. Following is the pairing and weighting comparison matrix and consistency test for each respondent. The following is the calculation for respondent 1 :

Table 2 Pairwise Comparison Matrix

\begin{tabular}{lccccc}
\hline \multicolumn{1}{c}{ Kriteria } & Quality & Price & $\begin{array}{c}\text { Payment } \\
\text { Flexibility }\end{array}$ & $\begin{array}{c}\text { Order } \\
\text { fulfillment }\end{array}$ & Time \\
\hline Quality & 1 & 3 & 5 & 3 & 5 \\
\hline Price & $1 / 3$ & 1 & 1 & 1 & 1 \\
\hline $\begin{array}{l}\text { Payment } \\
\text { Flexibility }\end{array}$ & $1 / 5$ & 1 & 1 & 1 & 1 \\
\hline $\begin{array}{l}\text { Order } \\
\text { fulfillment }\end{array}$ & $1 / 3$ & 1 & 1 & 1 & 1 \\
\hline Time & $1 / 5$ & 1 & 1 & 1 & 1 \\
\hline \multicolumn{1}{c}{ Total } & 2,07 & 7 & 9 & 7 & 9 \\
\hline & & & & &
\end{tabular}


After the data is processed using a paired matrix then make priority synthesis. Priority synthesis is done by calculating the criteria for pairwise comparison criteria divided by the total criteria themselves. Following is the priority synthesis calculation:

Table 3 Priority Synthesis

\begin{tabular}{lccccc}
\hline \multicolumn{1}{c}{ Kriteria } & Quality & Price & $\begin{array}{c}\text { Payment } \\
\text { Flexibility }\end{array}$ & $\begin{array}{c}\text { Order } \\
\text { fulfillment }\end{array}$ & Time \\
\hline Quality & 0,48 & 0,43 & 0,56 & 0,43 & 0,56 \\
\hline Price & 0,16 & 0,14 & 0,11 & 0,14 & 0,11 \\
\hline Payment Flexibility & 0,10 & 0,14 & 0,11 & 0,14 & 0,11 \\
\hline Order fulfillment & 0,16 & 0,14 & 0,11 & 0,14 & 0,11 \\
\hline Time & 0,10 & 0,14 & 0,11 & 0,14 & 0,11 \\
\hline
\end{tabular}

After obtaining the priority synthesis results, the priority weight calculation is then performed to obtain the results of the weight of each criterion. Determination of criteria weights is done by summing the priority synthesis results and dividing by the number of criteria (n). Following is the calculation of the priority weights for each criterion:

Table 4 Weight on each criterion

\begin{tabular}{lccccccc}
\hline \multicolumn{1}{c}{ Kriteria } & Quality & Price & $\begin{array}{c}\text { Payment } \\
\text { Flexibility }\end{array}$ & $\begin{array}{c}\text { Order } \\
\text { fulfillment }\end{array}$ & Time & Total & weight \\
\hline Quality & 0,48 & 0,43 & 0,56 & 0,43 & 0,56 & 2,45 & 0,49 \\
\hline Price & 0,16 & 0,14 & 0,11 & 0,14 & 0,11 & 0,67 & 0,13 \\
\hline $\begin{array}{l}\text { Payment } \\
\text { Flexibility }\end{array}$ & 0,10 & 0,14 & 0,11 & 0,14 & 0,11 & 0,60 & 0,12 \\
\hline $\begin{array}{l}\text { Order } \\
\text { fulfillment }\end{array}$ & 0,16 & 0,14 & 0,11 & 0,14 & 0,11 & 0,67 & 0,13 \\
\hline Time & 0,10 & 0,14 & 0,11 & 0,14 & 0,11 & 0,60 & 0,12 \\
\hline \multicolumn{7}{c}{ Total } \\
\hline
\end{tabular}

To find out the consistency of the answers given by respondents, a consistency test is needed by using the following calculations:

$$
\mathrm{CI}=\frac{\lambda \mathrm{maks}-\mathrm{n}}{\mathrm{n}-1}
$$

$\lambda$ maks $=\sum$ maks $/ \mathrm{n}$

$$
\begin{aligned}
& =\frac{\frac{2.50}{0,49}+\frac{0.67}{0,13}+\frac{0.61}{0,12}+\frac{0.67}{0,13}+\frac{0.61}{0,12}}{5} \\
& =\frac{5,10+5,08+5,02+5,08+5,02}{5}=5,04
\end{aligned}
$$

$\mathrm{n}=5$

$\mathrm{CI}=(5,04-5) /(5-1)=0,01$

Keterangan : CI : Consistency Index

$\lambda$ maks :Maximum Eigenvalue

$\mathrm{n}$ :Matrix order

$$
\mathrm{CR}=\frac{\mathrm{CI}}{\mathrm{RI}} \text {. }
$$

$\mathrm{RI}=1,12$

$\mathrm{CR}=0,01 / 1,12=0,01<0,1$ (Konsisten)

Based on the calculation results using the AHP method, two respondents all showed consistent results, then the average weighting of each criterion would then be calculated. The following is the average weighting of each criterion: 
Table 5 Calculation of average weighting criteria

\begin{tabular}{lccccc}
\hline \multicolumn{1}{c}{ Responden } & Quality & Price & $\begin{array}{c}\text { Payment } \\
\text { Flexibility }\end{array}$ & $\begin{array}{c}\text { Order } \\
\text { fulfillment }\end{array}$ & Time \\
\hline Respondent 1 & 0,49 & 0,13 & 0,12 & 0,13 & 0,12 \\
\hline Respondent 2 & 0,23 & 0,23 & 0,12 & 0,38 & 0,04 \\
\hline $\begin{array}{l}\text { Average } \\
\text { Weight }\end{array}$ & 0,36 & 0,18 & 0,12 & 0,26 & 0,08 \\
\hline
\end{tabular}

Based on the sum of the criteria weighted average of the two respondents it is seen that the criteria that have the highest weight value are the quality criteria with a weight of 0.36 . With the results of data processing in this study, the results are that quality is the most influential criterion in selecting suppliers or evaluating suppliers. According to Firman (2016) states that quality can be interpreted as conformity to consumer expectations with what they feel when consuming a product. So from that quality becomes an important thing for the hospital because with good quality drugs it will be able to meet the needs of patients and in accordance with patient expectations. Then the criteria that have the lowest weight value among the five criteria are the time criteria with a weight of 0.08 .

\section{Ranking with the PROMETHEE method}

Data obtained through distributing questionnaires to the makers of purchasing decisions in RSUD Padangwill then be processed using the PROMETHEE method. In the first step is to calculate the type and parameters of the preference function, as for the calculation results from the results of the type of preference and parameter values in this study as follows:

Table 6 Type and Parameter Function Preferences

\begin{tabular}{|c|c|c|c|c|c|c|c|c|}
\hline \multirow{2}{*}{ No } & \multirow{2}{*}{ Criteria } & \multicolumn{3}{|c|}{ Alternative } & \multirow{2}{*}{ Kaidah } & \multirow{2}{*}{$\begin{array}{l}\text { Type of } \\
\text { criteria }\end{array}$} & \multirow{2}{*}{$\mathbf{P}$} & \multirow{2}{*}{ weight } \\
\hline & & A & B & C & & & & \\
\hline 1 & Quality & 4,25 & 4,75 & 4,25 & Max & Linear & 0,12 & 0,36 \\
\hline 2 & Price & 5,00 & 5,00 & 5,00 & Max & Linear & 0,00 & 0,18 \\
\hline 3 & $\begin{array}{l}\text { Payment } \\
\text { Flexibility }\end{array}$ & 4,00 & 4,50 & 4,25 & Max & Linear & 0,02 & 0,12 \\
\hline 4 & $\begin{array}{l}\text { Order } \\
\text { fulfillment }\end{array}$ & 4,25 & 5,00 & 4,00 & Max & Linear & 0,13 & 0,26 \\
\hline 5 & Time & 3,00 & 3,00 & 4,00 & Max & Linear & 0,05 & 0,08 \\
\hline
\end{tabular}

In table 6 the weight values used are obtained from the results of calculations in the previous AHP method. The value for each alternative is obtained based on the average results of the research questionnaire given to two respondents. Next is to calculate the degree of preference, the calculation of the degree of preference is done on each alternative compared to other alternatives based on table 6. The following are the results of degrees of preference:

Table 7 Degree of Preference

\begin{tabular}{cccccc}
\hline Alternative & Quality & Price & $\begin{array}{c}\text { Payment } \\
\text { Flexibility }\end{array}$ & $\begin{array}{c}\text { Order } \\
\text { fulfillment }\end{array}$ & Time \\
\hline Weight & 0,36 & 0,18 & 0,12 & 0,26 & 0,08 \\
\hline$(\mathrm{A}, \mathrm{B})$ & 0 & 0 & 0 & 0 & 0 \\
\hline$(\mathrm{B}, \mathrm{A})$ & 1 & 0 & 1 & 1 & 0 \\
\hline$(\mathrm{A}, \mathrm{C})$ & 0 & 0 & 0 & 1 & 0 \\
\hline$(\mathrm{C}, \mathrm{A})$ & 0 & 0 & 1 & 0 & 1 \\
\hline$(\mathrm{B}, \mathrm{C})$ & 1 & 0 & 1 & 1 & 0 \\
\hline$(\mathrm{C}, \mathrm{B})$ & 0 & 0 & 0 & 0 & 1 \\
\hline
\end{tabular}


Furthermore, by calculating the preference index, the calculation of the reference index is obtained by multiplying the weight of the AHP method with the results of reference degrees in table 7 . The following are the results of the calculation of preference indices:

\section{Table 8 Preference Index}

\section{Alternative Preference Index}

\begin{tabular}{ll}
\hline$(\mathrm{A}, \mathrm{B})$ & 0,00 \\
\hline$(\mathrm{B}, \mathrm{A})$ & 0,74 \\
\hline$(\mathrm{A}, \mathrm{C})$ & 0,26 \\
\hline$(\mathrm{C}, \mathrm{A})$ & 0,20 \\
\hline$(\mathrm{B}, \mathrm{C})$ & 0,74 \\
\hline$(\mathrm{C}, \mathrm{B})$ & 0,08 \\
\hline
\end{tabular}

The Preference Index is determined based on the value of the outsourcing relationship on each criterion of each alternative. Indection preferences will be used to determine the leaving flow and entering flow values in this study. The following is the calculation of leaving flow and entering flow:

Table 9 Leaving flow dan Entering flow

\begin{tabular}{ccccc}
\hline Alternative & A & B & C & Leaving \\
\hline A & 0,00 & 0,00 & 0,26 & 0,13 \\
\hline B & 0,74 & 0,00 & 0,74 & 0,74 \\
\hline C & 0,20 & 0,08 & 0,00 & 0,14 \\
\hline Entering & 0,47 & 0,04 & 0,50 &
\end{tabular}

In leaving the highest ranking flow obtained based on the highest leaving flow value from several alternatives available. Whereas for ranking entering flow values are obtained based on the lowest entering flow value. The last step to get the supplier ranking results is to find the net flow value. The ranking results are obtained by reducing the leaving flow and entering flow values that have been sought in the previous calculations. The following are the results of the calculation of net flow and supplier rank:

Table 10 Net Flow Calculation

\begin{tabular}{ccccc}
\hline Alternative & Leaving & Entering & Net Flow & Ranking \\
\hline A & 0,13 & 0,47 & $-0,34$ & 2 \\
\hline B & 0,74 & 0,04 & 0,70 & 1 \\
\hline C & 0,14 & 0,50 & $-0,36$ & 3 \\
\hline
\end{tabular}

Based on the results of the calculation of Net flow value, where the greater the value of net flow shows the greater the priority. From the calculations that have been done above, we get an alternative ranking, the alternative that has the highest ranking is supplier B with a net flow value of 0.70 . Furthermore, the supplier who gets the second rank is supplier A with a net flow value of -0.34 and for suppliers with the last rating is supplier $C$ with a net flow value of -0.36 .

\section{Conclusions}

Based on the results of the study using the AHP and PROMETHEE methods at RSUD Padang, it can be concluded that, among the criteria of quality, price, payment flexibility, order fulfillment and time, the criteria that have the highest weight in supplier selection at RSUD Padang are quality criteria weighing 0.36. These criteria will also be used by RSUD Padangif at any time the hospital is authorized by the government or the ministry to find or choose their own supplier. After evaluating three suppliers, the drug supplier's ranking results were obtained at RSUD Padang that supplier B 
was the first rank supplier with a net flow value of 0.70 . Supplier B is considered to be the best supplier aside from the results of net flow having the highest value and also supplier B having good quality among several suppliers used.

\section{References}

Corrente, S., Figueira, J. R., \& Greco, S. (2014). The SMAA-PROMETHEE method. European Journal of Operational Research, 239(2), 514-522. https://doi.org/10.1016/j.ejor.2014.05.026

Dong, F. (2015). Coal suppliers Evaluation Model Based on AHP and. International Conference on Education Reform and Modern Management, 359-362.

Firman. (2016). Analisis Peran Quality Management Practice dan Internal Knowledge Transfer Terhadap Kinerja Organisasional Pada Perguruan Tinggi Negeri di Kota Padang. Jurnal Praktik Bisnis, 5(1), 37-50.

Ghodsypour, S. H., \& O'Brien, C. (1998). A decision support system for supplier selection using an integrated analytic hierarchy process and linear programming. International Journal of Production Economics, 56-57, 199-212. https://doi.org/10.1016/S0925-5273(97)00009-1

Heizer, J., \& Render, B. (2005). Manajemen Operasi (7th ed.). Jakarta: Salemba Empat.

Huseyinozder, E. (2017). SUPPLIER SELECTION PROBLEM WITH USING MULTI-CRITERIA DECISION MAKING METHODS : A CASE STUDY IN A GAS MASK FACTORY. International Journal Of Management and Applied Science, 3(7), 65-69.

Kasirian, M. N., Yusuff, R. M., \& Y, I. M. (2010). Application of AHP and ANP in supplier selection process-a case in an automotive company. International Journal of Management Science and Engineering Management, 5(2), 125-135. https://doi.org/10.1080/17509653.2010.10671100

Kull, T. J., \& Talluri, S. (2008). A Supply Risk Reduction Model Using Integrated Multicriteria Decision Making. IEEE Transactions On Engineering Management, 55(3), 409-419. https://doi.org/10.1109/TEM.2008.922627

Lin, C. T., Chen, C. B., \& Ting, Y. C. (2011). An ERP model for supplier selection in electronics industry. Expert Systems with Applications, 38(3), 1760-1765. https://doi.org/10.1016/j.eswa.2010.07.102

Macharis, C., Springael, J., De Brucker, K., \& Verbeke, A. (2004). PROMETHEE and AHP: The design of operational synergies in multicriteria analysis - Strengthening PROMETHEE with ideas of AHP. European Journal of Operational Research, 153(2), 307-317. https://doi.org/10.1016/S03772217(03)00153-X

Monczka, T., \& Handifield. (2005). Purchasing \& Suplly Chain Management (3rd editio). Atlantic:Thomson.

Murat, S., Kazan, H., \& Coskun, S. S. (2015). An Application for Measuring Performance Quality of Schools by Using the PROMETHEE Multi-Criteria Decision Making Method. Procedia - Social and Behavioral Sciences, 195, 729-738. https://doi.org/10.1016/j.sbspro.2015.06.344

Nair, Anand, and Ajay Das. 2015. "Strategic Purchasing Participation, Supplier Selection, Supplier Evaluation and Purchasing P Erformance." Journal of Production Research.

$\mathrm{Ng}$, W. L. (2008). An efficient and simple model for multiple criteria supplier selection problem. European Journal of Operational Research, 186(3), 1059-1067. https://doi.org/10.1016/j.ejor.2007.01.018

Nugroho, B. A. 2012. Metode Kuantitatif: Pendekatan Pengambilan Keputusan Untuk Ilmu Sosial Dan Bisnis. Jakarta: Salemba Humanika.

Nydick, R. L., \& Hill, R. P. (1992). Using the Analytic Hierarchy Process to Structure the Supplier Selection Procedure. International Journal of Purchasing and Materials Management, 28(2), 31-36. https://doi.org/10.1111/j.1745-493X.1992.tb00561.x

Özkan, B., Başlıgil, H., \& Şahin, N. (2011). Supplier selection using analytic hierarchy process: an application from Turkey. Proceedings of the World Congress on Engineering, II, 4-9. Retrieved from https://pdfs.semanticscholar.org/1655/3d5616899bcdae525e9f443d167047e25a9f.pdf\%0Ahttp://w ww.iaeng.org/publication/WCE2011/WCE2011_pp1160-1165.pdf 
Saaty, T. . (1993). Pengambilan Keputusan Bagi Para Pemimpin, Proses Hirarki Analitik untuk Pengambilan Keputusan dalam Situasi yang Kompleks. Jakarta: Pustaka Binama Presindo.

Sevkli, M., Zaim, S., Turkyilmaz, A., \& Satir, M. (2010). An application of fuzzy TOPSIS method for supplier selection. IEEE International Conference on Fuzzy System, (July). https://doi.org/10.1109/FUZZY.2010.5584006

Shahroudi, K., \& Tonekaboni, S. M. S. (2012). Application of Topsis Method To Supplier Selection in Iran Auto Supply Chain. Journal of Global Strategic Management, 6(2), 123-131. https://doi.org/10.20460/JGSM.2012615779

Shakey, B. K. (2013). Supplier Selection Using AHP and Engineering. International Journal Of Scientific Research, 2(6), 156-160.

Singh.Rajesh, Sharma, S. ., \& Pandey, P. (2012). SUPPLIER SELECTION: A GOAL PROGRAMMING APPROACH. International Journal Of Mechanical Engineering And Technology, 3(1), 46-63.

Stevenson, W. ., \& Chuong, S. . (2010). Operation Management An Asian Perspective. New York: McGrow-Hill.

Ware, N. R., Singh, S. P., \& Banwet, D. K. (2013). A mixed-integer non-linear program to model dynamic supplier selection problem. Expert Systems with Applications, 671-678. https://doi.org/10.1016/j.eswa.2013.07.092

Weber, C. A., \& Current, J. R. (1993). A multiobjective approach to vendor selection. European Journal of Operational Research, 68(2), 173-184. https://doi.org/10.1016/0377-2217(93)90301-3

Wu, T., \& Blackhurst, J. (2009). Supplier evaluation and selection: An augmented DEA approach. International Journal of Production Research, 47(16), 4593-4608. https://doi.org/10.1080/00207540802054227

$\mathrm{Yu}$, Xiaohan, Zeshui Xu, and Ying Ma. 2013. "Prioritized Multi-Criteria Decision Making Based on the Idea of PROMETHEE." Procedia Computer Science 17: 449-56. 